\title{
Effective Partial Alkynylation of Carboxylic Acid Derivatives to Alkynyl Ketones
}

\author{
Sang Jun Yim, Min Hyeok Kim, and Duk Keun $\mathrm{An}^{*}$ \\ Department of Chemistry, Kangwon National University, \\ and Institute for Molecular Science and Fusion Technology, Chuncheon 200-701, Korea. *E-mail :dkan@kangwon.ac.kr \\ Received December 1, 2009, Accepted December 25, 2009
}

The reaction of carboxylic acid derivatives such as esters, acid chlorides and acid anhydrides with alkynyl lithiums in the presence of lithium morpholinide and $\mathrm{BF}_{3} \cdot \mathrm{OEt}_{2}$ gave alkynyl ketones in good yield (73-96\%).

Key Words: Partial alkynylation, Ynone, Ester, Acid chloride, Acid anhydride

\section{Introduction}

Alkynyl ketones are some of the versatile intermediates widely used in the synthesis of natural products with significant biological activity and as heterocyclic ligands or precursors for materials with interesting properties. ${ }^{1}$ They have also been used in the preparation of various heterocyclic compounds such as furan, pyrrole, quinoline and pyrazole derivatives via sequential nucleophilic additions and cyclizations. ${ }^{2}$ Furthermore, the one-pot process has recently gained a considerable and steadily increasing academic, economic and ecological interest because it addresses very fundamental principles of organic synthesis efficiency and reaction design. Thus, several approaches for such synthesis have been reported, mostly involving stoichiometric nucleophilic addition and including oxidation of propargyl alcohols. Alkynyl ketones can also be synthesized using transition-metal-catalyzed methods from acid chloride. ${ }^{3}$ The yields of alkynyl ketones from acid chlorides using both methods are moderate to good, and the catalytic reactions required a very high temperature. On the other hand, in case of esters, the preparation of the alkynyl ketones proceeds via addition reaction using metal acetylides such as alkynyl lithium ${ }^{4}$ or alkynyl lithium with $\mathrm{BF}_{3} \cdot \mathrm{OEt}_{2}{ }^{5}$ This addition reaction could be one of the convenient ways to synthesize alkynyl ketones. However, these methods have great problems in the use of aromatic esters because of the formation of tertiary alcohol or lack of reaction in the alkynylation of aromatic esters. Recently, we reported that a new one-pot method for synthesizing aromatic alkynyl ketones from aromatic esters has been

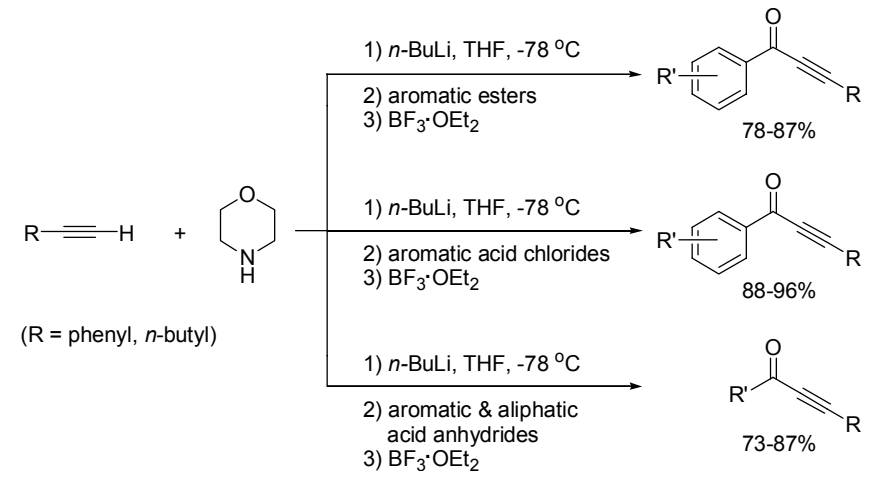

Scheme 1 developed with good yield $(78-87 \%){ }^{6}$ In the course of our extension work in the area of partial alkynylation of carboxylic acid derivatives, we decided to investigate the synthesis of alkynyl ketones from acid chlorides and acid anhydrides including esters. Herein, we wish to report a new and efficient method for synthesizing alkynyl ketones which is based on partial alkynylation of aromatic acid chlorides and acid anhydrides, also involving aromatic esters using lithium morpholinide and alkynyl lithiums prepared from morpholine and alkynes using $n$-butyllithium with $\mathrm{BF}_{3} \cdot \mathrm{OEt}_{2}$ (Scheme 1).

\section{Results and Discussion}

Recently, we investigated the reaction of ethyl benzoate by treatment with lithium morpholinide and phenylacetylenic lithium at $-78^{\circ} \mathrm{C}$, which afforded the corresponding amide in $91 \%$ yield. On the other hand, when $\mathrm{BF}_{3} \cdot \mathrm{OEt}_{2}$ as Lewis acid was added to the reaction mixture under the same reaction conditions, the reaction afforded the corresponding aromatic alkynyl ketone in $83 \%$ yield. This result suggests that the lithium morpholinide as a nucleophile was more reactive than alkynyl lithium to aromatic esters at $-78^{\circ} \mathrm{C}$ (Scheme 2).

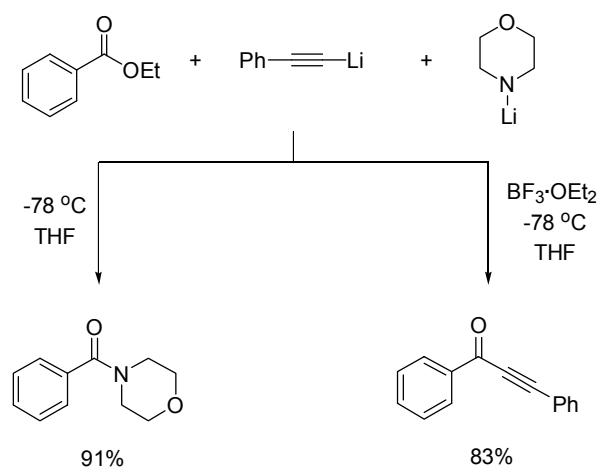

Scheme 2

Next, as shown in Table 1, we examined partial alkynylation of aromatic esters to aromatic alkynyl ketones by using various secondary amines such as diethylamine, dihexylamine, dicyclohexylamine, piperidine, pyrrolidine, pyrrole and indole. Among those examined, we could not find results superior to those obtained with morpholine. 
Table 1. Partial alkynylation of ethyl benzoate in the presence of various secondary amines

\begin{tabular}{|c|c|c|c|}
\hline \multirow{2}{*}{$\mathrm{Ph}=$} & \multirow{2}{*}{ sec-amines } & \multicolumn{2}{|c|}{ 1) $n$-BuLi, THF, $-78^{\circ} \mathrm{C}$} \\
\hline & & \multicolumn{2}{|l|}{$\begin{array}{l}\text { 2) ethyl benzoate } \\
\text { 3) } \mathrm{BF}_{3} \cdot \mathrm{OEt}_{2}\end{array}$} \\
\hline Entry & \multicolumn{2}{|c|}{ sec-amines } & Isolated Yield (\%) ${ }^{a}$ \\
\hline 1 & \multicolumn{2}{|c|}{ diethylamine } & 0 \\
\hline 2 & \multicolumn{2}{|c|}{ dihexylamine } & 67 \\
\hline 3 & \multicolumn{2}{|c|}{ dicyclohexylamine } & 0 \\
\hline 4 & \multicolumn{2}{|c|}{ piperidine } & 62 \\
\hline 5 & \multicolumn{2}{|c|}{ morpholine } & 83 \\
\hline 6 & \multicolumn{2}{|c|}{ pyrrolidine } & 7 \\
\hline 7 & \multicolumn{2}{|l|}{ pyrrole } & 0 \\
\hline 8 & \multicolumn{2}{|l|}{ indole } & 0 \\
\hline
\end{tabular}

${ }^{a}$ Ethyl benzoate : phenyl acetylene : amines : $n$-BuLi : $\mathrm{BF}_{3} \cdot \mathrm{OEt}_{2}=1: 3$ : $1: 4: 1$.

With these results in hand, we anticipated that the treatment of aromatic esters with lithium morpholinide and alkynyl lithiums in the presence of $\mathrm{BF}_{3} \cdot \mathrm{OEt}_{2}$ might open up one-pot access to aromatic alkynyl ketones. Table 2 summarizes the results of successive treatment of representative aromatic esters.

As shown in Table 2, aromatic alkynyl ketones can be readily synthesized from ethyl, isopropyl, $t$-butyl and benzyl benzoate in $80-87 \%$ yield (entries 2-5). Also noteworthy fact that, these kinds of alkyne can tolerate the reaction with various aromatic esters, the reaction opens up easy access to aromatic alkynyl ketones containing aromatic and aliphatic alkynes (entries 1 and 2). Furthermore, benzoates with electron-withdrawing substituents such as methyl 3-chlorobenzoate and ethyl 4-bromobenzoate, and electron-donating substituents such as methyl 3,4-dimethoxybenzoate and isopropyl 3-methylbenzoate were readily converted to the corresponding aromatic alkynyl ketones in $78-87 \%$ yield (entries 6-9). Similarly, poly-aromatic ester such as isopropyl naphthoate gave the corresponding alkynyl ketone in $82 \%$ yield (entry 10 ).

Also, we were carried out alkynylation with benzoyl chloride and caproyl chloride, respectively, using our reaction method to confirm the possibility of partial alkynylation of acid chlorides. We successfully obtained the corresponding aromatic alkynyl ketone from benzoyl chloride. However, we were unable to synthesize the aliphatic alkynyl ketones from caproyl chlorides using this method because the mixtures produced included condensation products from aliphatic substrates. Table 3 summarizes the results of successive reactions with representative aromatic acid chlorides.

As shown in Table 3, benzoyl chloride was smoothly reacted with 1-hexyne or phenylacetylene to produce the corresponding alkynyl ketone in $92 \%$ and $94 \%$ yield, respectively (entries 1 and 2). These results mean that some kinds of alkyne can tolerate the reaction with various aromatic acid chlorides, the reaction opening up easy access to aromatic alkynyl ketones containing aromatic and aliphatic alkynes. Under identical conditions, acid chlorides with electron-withdrawing substituents, such as 3-chlorobenzoyl chloride, 4-chlorobenzoyl chloride and
Table 2. Yields of aromatic alkynyl ketones in the partial alkynylation of representative aromatic esters ${ }^{a}$

Entry

${ }^{a}$ Ethyl benzoate : acetylene : morpholine $: n$-BuLi $: \mathrm{BF}_{3} \cdot \mathrm{OEt}_{2}=1: 3: 1:$ $4: 1$. Isolated yield after column chromatography in the presence of $\mathrm{Et}_{3} \mathrm{~N}$.

3-bromobenzoyl chloride, and electron-donating substituents, such as 4-methoxybenzoyl chloride and 3-methylbenzoyl chloride, were readily converted to the corresponding alkynyl ketones in 88 - 94\% yield (entries 3-7). Similarly, reduction of other aromatic acid chlorides such as 2-naphthoyl chloride, a polyaromatic acid chloride, and 2-furoyl chloride, a heterocyclic acid chloride, successfully gave the corresponding alkynyl ketones in $91 \%$ and $96 \%$ yield, respectively (entries 8 and 9).

Furthermore, we decided to apply the same methodology to prepare alkynyl ketones from acid anhydrides because making the alkynyl ketones from acid anhydrides is also an important synthetic route in organic synthesis too. The results for two representative kinds of acid anhydride are summarized in Table 4. It is noteworthy in these results that, unlike esters and acid chlorides, the method can achieve partial alkynylation of both aromatic and aliphatic acid anhydrides.

Scheme 3 shows plausible mechanisms of these reactions, 
Table 3. Yields of aromatic alkynyl ketones in the partial alkynylation of representative aromatic acid chlorides ${ }^{a}$

Entry

${ }^{a}$ Acid chloride : acetylene : piperidine $: n$-BuLi : $\mathrm{BF}_{3} \cdot \mathrm{OEt}_{2}=1: 3: 1: 4: 1$. ${ }^{b}$ Isolated yield after silica column chromatography in the presence of $\mathrm{Et}_{3} \mathrm{~N}$.

Table 4. One-pot synthesis of alkynyl ketones from acid anhydrides ${ }^{a}$

Entry Acid Anhydride

\footnotetext{
${ }^{a}$ Anhydride : acetylene : morpholine $: n$-BuLi $: \mathrm{BF}_{3} \cdot \mathrm{OEt}_{2}=1: 3: 1: 4: 1$. ${ }^{b}$ Isolated yield after silica column chromatography in the presence of $\mathrm{Et}_{3} \mathrm{~N} .{ }^{c}$ Anhydride : acetylene : morpholine : $n$-BuLi $: \mathrm{BF}_{3} \cdot \mathrm{OEt}_{2}=1: 3: 1: 4$ $: 2$.
}

for instance the reaction of ethyl benzoate to the corresponding alkynyl ketone. Reaction of equimolar ethyl benzoate and lithium morpholinide rapidly forms stable intermediate 1 by attack of the morpholinyl group on carbonyl carbon of the ester, and this is quickly transformed into a more stable intermediate, amide 2. The resulting amide 2 was then reacted with $\mathrm{BF}_{3}$. $\mathrm{OEt}_{2}$ as Lewis acid and alkynyl lithium at $-78^{\circ} \mathrm{C}$ to afford the aromatic alkynyl ketone $\mathbf{3}$ in good yield.

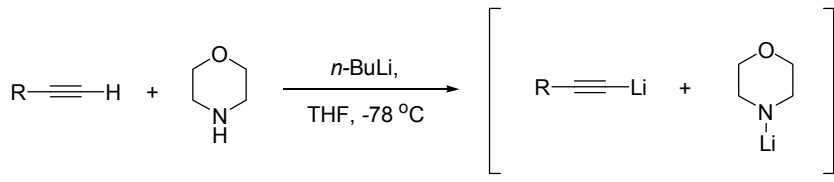

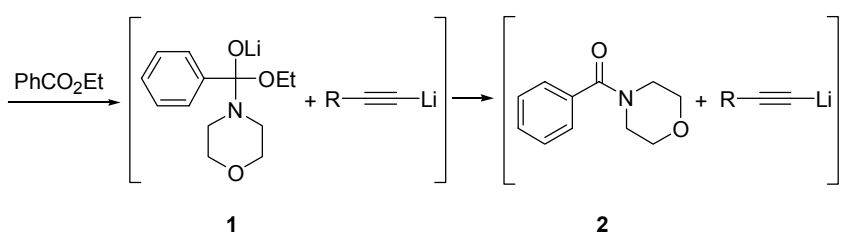<smiles>[R]C#CC(=O)c1ccccc1</smiles>

Scheme 3

\section{Conclusion}

We found that a one-pot method for synthesizing aromatic alkynyl ketones from aromatic esters could be developed. Thus, it now becomes possible to synthesize not only aliphatic alkynyl ketones but also aromatic alkynyl ketones from esters in good yield $(78-87 \%)$. These results show that the new methodology is an effective and useful method for synthesis of aromatic alkynyl ketones from various substituted aromatic acid chlorides in very good yield (88 - 96\%). Furthermore, this method can also be successfully applied to synthesize alkynyl ketones from acid anhydrides in good yield (73 - 87\%). Therefore this new method is believed to be an alternative method for partial alkynylation of aromatic esters, aromatic acid chlorides and acid anhydrides to form the corresponding alkynyl ketones.

\section{Experimental Section}

General. All glassware used was dried thoroughly in an oven, assembled hot, and cooled under a stream of dry nitrogen prior to use. All reactions and manipulation of air- and moisturesensitive materials were carried out using standard techniques for handling air-sensitive materials. All chemicals were commercial products of the highest purity which were further purified by standard methods before use. THF was dried over sodium-benzophenone and distilled. $n$-Butyllithium, ester, acid chloride, acid anhydrides, morpholine and $\mathrm{BF}_{3} \cdot \mathrm{OEt}_{2}$ were purchased from Aldrich Chemical Company. ${ }^{1} \mathrm{H}-\mathrm{NMR}$ spectra were 
measured at 300 or $400 \mathrm{MHz}$ with $\mathrm{CDCl}_{3}$ as a solvent at ambient temperature unless otherwise indicated and the chemical shifts were recorded in parts per million downfield from tetramethylsilane $(\delta=0 \mathrm{ppm})$ or based on residual $\mathrm{CHCl}_{3}(\delta=7.26 \mathrm{ppm})$ as an internal standard. ${ }^{13} \mathrm{C}$ NMR spectra were recorded at 75 or $100 \mathrm{MHz}$ with $\mathrm{CDCl}_{3}$ as a solvent and referenced to the central line of the solvent $(\delta=77.0 \mathrm{ppm})$. The coupling constants $(J)$ are reported in hertz. Analytical thin-layer chromatography (TLC) was performed on glass precoated with silica gel (Merck, silica gel $60 \mathrm{~F}_{254}$ ). Column chromatography was carried out using 70 - 230 mesh silica gel (Merck) at normal pressure.

Representative procedure for the synthesis of 1,3-diphenyl2-propyne-1-one from ethyl benzoate. To a solution of morpholine $(0.09 \mathrm{~mL}, 1.0 \mathrm{mmol})$ and phenylacetylene $(0.33 \mathrm{~mL}$, $3.0 \mathrm{mmol})$ in THF ( $5 \mathrm{~mL}$ ) was slowly added $n$-butyllithium (6.4 mL, 2.5 $\mathrm{M}$ in hexane, $4 \mathrm{mmol}$ ) at $-78^{\circ} \mathrm{C}$. Stirring was continued for $10 \mathrm{~min}$ at $-78{ }^{\circ} \mathrm{C}$; to this was added ethyl benzoate $(0.14 \mathrm{~mL}, 1 \mathrm{mmol})$ and the mixture was stirred for $10 \mathrm{~min}$ at the same temperature. To this was added dropwise $\mathrm{BF}_{3} \cdot \mathrm{OEt}_{2}$ $(0.13 \mathrm{~mL}, 1 \mathrm{mmol})$. After being stirred for $30 \mathrm{~min}$ at $-78^{\circ} \mathrm{C}$, the reaction mixture was quenched with saturated aqueous $\mathrm{NH}_{4} \mathrm{Cl}$ $(10 \mathrm{~mL})$ and extracted with diethyl ether $(2 \times 10 \mathrm{~mL})$. The combined organic layers were dried over $\mathrm{MgSO}_{4}$ and filtered. The residue was purified by column chromatography on silica gel in the presence of $\mathrm{Et}_{3} \mathrm{~N}$ to afford 1,3-diphenylprop-2-yn-1-one (172 mg, 83\%); ${ }^{1} \mathrm{H}-\mathrm{NMR}\left(300 \mathrm{MHz}, \mathrm{CDCl}_{3}\right) \delta$ 7.41-7.55 (m, $5 \mathrm{H}), 7.62-7.72(\mathrm{~m}, 3 \mathrm{H}), 8.22-8.25(\mathrm{~m}, 2 \mathrm{H}) ;{ }^{13} \mathrm{C} \mathrm{NMR}(75 \mathrm{MHz}$, $\left.\mathrm{CDCl}_{3}\right) \delta 86.92,93.11,120.17,128.64,128.70,129.59,130.80$, 133.08, 134.12, 136.94, 178.02.

1-Phenylhept-2-yn-1-one: ${ }^{1} \mathrm{H}-\mathrm{NMR}\left(300 \mathrm{MHz}, \mathrm{CDCl}_{3}\right) \delta$ $0.97(\mathrm{t}, J=7.27 \mathrm{~Hz}, 3 \mathrm{H}), 1.47-1.55(\mathrm{~m}, 2 \mathrm{H}), 1.62-1.70(\mathrm{~m}, 2 \mathrm{H})$, $2.51(\mathrm{t}, J=7.05 \mathrm{~Hz}, 2 \mathrm{H}), 7.44-7.50(\mathrm{~m}, 2 \mathrm{H}), 7.57-7.60(\mathrm{~m}, 1 \mathrm{H})$, 8.12-8.16 (m, 2H); ${ }^{13} \mathrm{CNMR}\left(75 \mathrm{MHz}, \mathrm{CDCl}_{3}\right) \delta 13.52,18.93$, 22.10, 29.88, 79.72, 96.83, 128.49, 129.56, 133.85, 137.01, 178.25 .

1-(3-Chlorophenyl)-3-phenylprop-2-yn-1-one: ${ }^{1} \mathrm{H}-\mathrm{NMR}$ (400 $\left.\mathrm{MHz}, \mathrm{CDCl}_{3}\right) \delta$ 7.42-7.53 (m, 4H), 7.59-7.62 (m,1H), 7.69-7.75 $(\mathrm{m}, 2 \mathrm{H}), 8.11(\mathrm{dd}, J=7.24,1.14 \mathrm{~Hz}, 1 \mathrm{H}), 8.18$ (st, $J=1.50 \mathrm{~Hz}$, $1 \mathrm{H}) ;{ }^{13} \mathrm{C}$ NMR $\left(100 \mathrm{MHz}, \mathrm{CDCl}_{3}\right) \delta 85.52,93.96,119.79$, $127.69,128.77,129.44,129.98,131.08,133.19,134.02,134.98$, $138.39,176.57$.

1-(4-Chlorophenyl)-3-phenylprop-2-yn-1-one: ${ }^{1} \mathrm{H}-\mathrm{NMR}(400$ $\left.\mathrm{MHz}, \mathrm{CDCl}_{3}\right) \delta$ 7.42-7.46 (m, 2H), 7.49-7.53 (m, 3H), 7.68-7.71 $(\mathrm{m}, 2 \mathrm{H}), 8.15-8.18(\mathrm{~m}, 2 \mathrm{H}) ;{ }^{13} \mathrm{C} \mathrm{NMR}\left(100 \mathrm{MHz}, \mathrm{CDCl}_{3}\right) \delta$ $86.58,93.65,119.90,128.75,129.02,130.88,130.99,133.12$, $135.31,140.74,176.69$.

1-(3-Bromophenyl)-3-phenylprop-2-yn-1-one: ${ }^{1} \mathrm{H}-\mathrm{NMR}$ (400 $\left.\mathrm{MHz}, \mathrm{CDCl}_{3}\right) \delta$ 7.39-7.46 (m, 3H), 7.49-7.54 (m, 1H), 7.69-7.71 $(\mathrm{m}, 2 \mathrm{H}), 7.75-7.77(\mathrm{~m}, 1 \mathrm{H}), 8.16(\mathrm{dt}, J=7.79,1.25 \mathrm{~Hz}, 1 \mathrm{H})$, 8.34 (st, $J=1.75 \mathrm{~Hz}, 1 \mathrm{H}) ;{ }^{13} \mathrm{C} \mathrm{NMR}\left(100 \mathrm{MHz}, \mathrm{CDCl}_{3}\right) \delta 86.48$, 94.05, 119.79, 122.91, 128.14, 128.77, 130.23, 131.09, 132.39, $133.19,136.92,138.58,176.47$.

1-(4-Bromophenyl)-3-phenylprop-2-yn-1-one: ${ }^{1} \mathrm{H}-\mathrm{NMR}$ (400 $\left.\mathrm{MHz}, \mathrm{CDCl}_{3}\right) \delta$ 7.42-7.46 (m, 2H), 7.49-7.53 (m, 1H), 7.65-7.70 $(\mathrm{m}, 4 \mathrm{H}), 8.07-8.10(\mathrm{~m}, 2 \mathrm{H}) ;{ }^{13} \mathrm{C} \mathrm{NMR}\left(100 \mathrm{MHz}, \mathrm{CDCl}_{3}\right) \delta$ $86.56,93.70,119.88,128.76,129.59,130.95,131.01,132.01$, $133.13,135.70,176.89$.

1-(4-Methoxyphenyl)-3-phenylprop-2-yn-1-one: ${ }^{1} \mathrm{H}-\mathrm{NMR}$ $\left(400 \mathrm{MHz} \mathrm{CDCl}_{3}\right) \delta 3.90(\mathrm{~s}, 3 \mathrm{H}), 6.97-7.01(\mathrm{~m}, 2 \mathrm{H}), 7.40-7.50$ (m, 3H), 7.66-7.69 (m, 2H), 8.18-8.22 (m, 2H); ${ }^{13} \mathrm{C} \mathrm{NMR} \mathrm{(100}$ $\left.\mathrm{MHz} \mathrm{CDCl}_{3}\right) \delta 55.61,86.93,92.32,113.90,120.37,128.66$, $130.32,130.59,132.00,132.97,164.50,176.70$.

1-(3,4-Dimethoxyphenyl)-3-phenylprop-2-yn-1-one: ${ }^{1} \mathrm{H}-$ NMR (300 MHz, $\left.\mathrm{CDCl}_{3}\right) \delta 3.98(\mathrm{~s}, 3 \mathrm{H}), 3.99(\mathrm{~s}, 3 \mathrm{H}), 6.97$ (d, $J=8.41 \mathrm{~Hz}, 1 \mathrm{H}), 7.39-7.49$ (m, 3H), 7.66-7.69 (m, 3H), 7.97 $(\mathrm{dd}, J=8.39,1.39 \mathrm{~Hz}, 1 \mathrm{H}) ;{ }^{13} \mathrm{C} \mathrm{NMR}\left(75 \mathrm{MHz}, \mathrm{CDCl}_{3}\right) \delta 56.08$, 56.21, 86.92, 32.31, 110.20, 110.34, 120.43, 125.79, 128.70, $130.58,130.62,132.96,149.17,154.43,176.69$.

3-Phenyl-1-m-tolylprop-2-yn-1-one: ${ }^{1} \mathrm{H}-\mathrm{NMR}(400 \mathrm{MHz}$, $\left.\mathrm{CDCl}_{3}\right) \delta 2.45(\mathrm{~s}, 3 \mathrm{H}), 7.39-7.51(\mathrm{~m}, 5 \mathrm{H}), 7.69(\mathrm{~d}, J=7.21 \mathrm{~Hz}$, $2 \mathrm{H}), 8.02(\mathrm{~s}, 1 \mathrm{H}), 8.04(\mathrm{~d}, J=7.39 \mathrm{~Hz}, 1 \mathrm{H}) ;{ }^{13} \mathrm{C}$ NMR $(100$ $\left.\mathrm{MHz}, \mathrm{CDCl}_{3}\right) \delta 21.35,87.02,92.88,120.23,127.13,128.52$, $128.69,129.79,130.74,133.05,134.99,136.93,138.51,178.24$.

1-(Naphthalen-6-yl)-3-phenylprop-2-yn-1-one: ${ }^{1} \mathrm{H}-\mathrm{NMR}$ $\left(400 \mathrm{MHz}, \mathrm{CDCl}_{3}\right) \delta$ 7.43-7.53 (m, 3H), 7.56-7.60 (m, 1H), 7.62-7.66 (m, 1H), 7.73-7.75 (m, 2H), $7.92(\mathrm{t}, J=9.00 \mathrm{~Hz}$, $2 \mathrm{H}), 8.03(\mathrm{~d}, J=8.03 \mathrm{~Hz}, 1 \mathrm{H}), 8.21(\mathrm{dd}, J=8.60,1.62 \mathrm{~Hz}$, $1 \mathrm{H}), 8.80(\mathrm{~s}, 1 \mathrm{H}) ;{ }^{13} \mathrm{C} \mathrm{NMR}\left(100 \mathrm{MHz}, \mathrm{CDCl}_{3}\right) \delta 87.08,93.06$, 120.24, 124.00, 126.97, 127.94, 128.57, 128.73, 129.04, 129.91, $130.80,132.43,132.68,133.08,134.45,136.18,177.97$.

1-(Furan-2-yl)-3-phenylprop-2-yn-1-one: ${ }^{1} \mathrm{H}-\mathrm{NMR}(400$ $\left.\mathrm{MHz}, \mathrm{CDCl}_{3}\right) \delta 6.61(\mathrm{dd}, J=3.55,1.58 \mathrm{~Hz}, 1 \mathrm{H}), 7.40-7.44(\mathrm{~m}$, $3 \mathrm{H}), 7.47-7.51(\mathrm{~m}, 1 \mathrm{H}), 7.65-7.67(\mathrm{~m}, 2 \mathrm{H}), 7.70(\mathrm{sd}, J=1.25$ $\mathrm{Hz}, 1 \mathrm{H}) ;{ }^{13} \mathrm{C} \mathrm{NMR}\left(100 \mathrm{MHz}, \mathrm{CDCl}_{3}\right) \delta 86.23,91.92,112.68$, $119.89,120.96,128.70,130.89,133.07,148.07,153.23,164.80$.

1-Phenyloct-1-yn-3-one: ${ }^{1} \mathrm{H}-\mathrm{NMR}\left(400 \mathrm{MHz}, \mathrm{CDCl}_{3}\right) \delta 0.92$ $(\mathrm{t}, J=6.99 \mathrm{~Hz}, 3 \mathrm{H}), 1.33-1.39(\mathrm{~m}, 4 \mathrm{H}), 1.71-1.79(\mathrm{~m}, 2 \mathrm{H})$, $2.66(\mathrm{t}, J=7.40 \mathrm{~Hz}, 2 \mathrm{H}) 7.36-7.40(\mathrm{~m}, 2 \mathrm{H}), 7.43-7.48(\mathrm{~m}$, 1H), 7.56-7.59 (m, 2H); ${ }^{13} \mathrm{C} \mathrm{NMR}\left(100 \mathrm{MHz}, \mathrm{CDCl}_{3}\right) \delta 13.91$, $22.42,23.88,31.17,45.53,87.85,90.57,120.07,128.62,130.65$, $133.04,188.39$.

Acknowledgments. This work was supported by National Research Foundation of Korea Grant funded by the Korea Government (2009-0066035) and the Central Laboratory of Kangwon National University. We are also grateful for the support of Brain Korea 21.

\section{References}

1. (a) Ramachandra, P. V.; Teodorovic, A. V.; Rangaishenvi, M. V.; Brown, H. C. J. Org. Chem. 1992, 57, 2379. (b) Rossi, R.; Bellina, F.; Biagetti, M.; Mannina, L. Tetrahedron: Asymmetry 1999, 10, 1163. (c) Adlington, R. M.; Baldwin, J. E.: Pritchard, G. J.; Spencer, K. C. Tetrahedron Lett. 2000, 41, 575. (d) Wender, P. A.; Bi, F. C.; Brodney, M. A.; Gosselin, F. Org. Lett. 2001, 3, 2105. (e) Sneddon, H. F.; Gaunt, M. J.; Ley, S. V. Org. Lett. 2003, 5, 1147.

2. (a) Coispeau, G.; Elguero, J.; Jacquier, R. Bull. Soc. Chim. Fr. 1970, 689. (b) Midland, M. M.; McDowell, D. C.; Hatch, R. L.; Tramontano, A. J. Am. Chem. Soc. 1980, 102, 867. (c) Utimoto, K.; Miwa, H.; Nozaki, H. Tetrahedron Lett. 1981, 22, 4277. (d) Brown, H. C.; Pai, G. G. J. Org. Chem. 1982, 47, 867. (e) Wills, M. S. B.; Danheiser, R. L. J. Am. Chem. Soc. 1998, 120, 9378. (f) Arcadi, A.; Marinelli, F.; Rossi, E. Tetrahedron 1999, 55, 13233. (g) Wang, X.; Tan, J.; Zhang, L. Org. Lett. 2000, 2, 3107. (h) Cabarrocas, G.; Ventura, M.; Maestro, M.; Villalgordo, J. M. Tetrahedron: Asymmetry 2000, 11, 2483. (i) Kel'in, A. V.; Sromek, A. W.; Gevorgyan, V. J. Am. Chem. Soc. 2001, 123, 2074. (j) Jeevanadam, A.; 
Narkunan, K.; Ling, Y.-C. J. Org. Chem. 2001, 66, 6014. (k) Kel' in, A. V.; Gevorgyan, V. J. Org. Chem. 2002, 67, 95. (1) Grotjahn, D. B.; Van, S.; Combs, D.; Lev, D. A.; Schneider, C.; Rideout, M.; Meyer, C.;. Hernandez, G.; Mejorado, L. J. Org. Chem. 2002, 67, 9200. (m) Savarin, C. G.; Murry, J. A.; Dormer, P. G. Org. Lett. 2002, 4, 2071. (n) Karpov, A. S.; Muller, T. J. J. Org. Lett. 2003, 5,3451 .
3. Alonso, D. A.; Nájera, C.; Pacheco, M. C. J. Org. Chem. 2004, 69, 1615 and references cited therein.

4. Humptman, H.; Mader, M. Synthesis 1978, 307.

5. Yamaguchi, M.; Shirato, K.; Eujiwara, S.; Hirao, I. Synthesis 1986, 421.

6. Yim, S. J.; Kwon, C. H.; An, D. K. Tetrahedron Lett. 2007, 48, 5393. 